\title{
Serosurvey for Leishmania spp., Toxoplasma gondii, Trypanosoma cruzi and Neospora caninum in neighborhood dogs in Curitiba-Paraná, Brazil
}

\author{
Inquérito sorológico para Leishmania spp., Toxoplasma gondii, Trypanosoma cruzi e \\ Neospora caninum em cães comunitários em Curitiba-Paraná, Brasil
}

Caroline Constantino ${ }^{1}$; Maysa Pellizzaro' ${ }^{1}$ Edson Ferraz Evaristo de Paula²; Thállitha Samih Wischral Jayme Vieira ${ }^{1}$; Ana Pérola Drulla Brandão ${ }^{3}$; Fernando Ferreira ${ }^{3}$; Rafael Felipe da Costa Vieira ${ }^{1}$; Helio Langoni ${ }^{4}$; Alexander Welker Biondo ${ }^{1 *}$

\begin{abstract}
${ }^{1}$ Laboratório de Zoonoses e Epidemiologia Molecular, Departamento de Medicina Veterinária, Universidade Federal do Paraná UFPR, Curitiba, PR, Brasil

${ }^{2}$ Rede de Defesa e Proteção Animal, Departamento de Pesquisa e Conservação da Fauna, Secretaria Municipal de Meio Ambiente, Curitiba, PR, Brasil

${ }^{3}$ Departamento de Medicina Veterinária Preventiva, Universidade de São Paulo - USP, São Paulo, SP, Brasil

${ }^{4}$ Núcleo de Pesquisa em Zoonoses - NUPEZO, Universidade Estadual Paulista - UNESP, Campus de Botucatu, Botucatu, SP, Brasil
\end{abstract}

Received April 13, 2016

Accepted June 27, 2016

\begin{abstract}
Neighborhood dogs may act as reservoirs for several zoonotic protozoan infections, particularly in urban areas, thus constituting a potential public health threat. Accordingly, the aim of the present study was to evaluate the exposure of neighborhood dogs to four protozoan pathogens in public areas with high levels of human movement in Curitiba, southern Brazil. Blood samples from 26 neighborhood dogs were screened by means of the indirect immunofluorescent antibody test (IFAT) for Leishmania spp., Toxoplasma gondii, Trypanosoma cruzi and Neospora caninum, and a questionnaire was answered by the respective keeper. A total of $8 / 26$ dogs (30.7\%) seroreactive to T. gondii, 3/26 (11.5\%) to N. caninum and $2 / 26(7.7 \%)$ to both were identified. All the samples were seronegative for T. cruzi and Leishmania spp. Pathogen seroreactivity was not associated with the daily human movements or other epidemiological variables investigated $(p>0.05)$. In conclusion, the low seroprevalence for T. gondii and N. caninum indicated low environmental and food risk for animal infection and the seronegativity for Leishmania spp. and T. cruzi may reflect the absence of these pathogens in urban areas of Curitiba. Moreover, neighborhood dogs may be used as environmental sentinels for the presence of protozoan pathogens and their vectors.
\end{abstract}

Keywords: Community dogs, urban area, sentinel animals, toxoplasmosis, neosporosis, IFAT.

\section{Resumo}

Cães comunitários podem atuar como reservatórios para algumas zoonoses causadas por protozoários, principalmente em áreas urbanas, constituindo potencial ameaça à saúde pública. Portanto, o objetivo do presente estudo foi avaliar a exposição de cães comunitários a quatro protozoários em áreas públicas com alta circulação de pessoas, em Curitiba, Sul do Brasil. Amostras de sangue de 26 cães comunitários foram testadas pela reação de imunofluorescência indireta (RIFI) para Leishmania spp., Toxoplasma gondii, Trypanosoma cruzi e Neospora caninum, e um questionário foi respondido pelo respectivo mantenedor. Um total de 8/26 (30,7\%) foram sororreagentes para T. gondii, 3/26 (11,5\%) para N. caninum e 2/26 (7,7\%) para ambos. Todas as amostras foram soronegativas para T. cruzi e Leishmania spp. Não houve associação entre sororreatividade para os patógenos pesquisados e o tráfego diário de pessoas e outras variáveis epidemiológicas analisadas ( $p>0.05$ ). Conclui-se a baixa soroprevalência para T. gondii e T. cruzi indica baixo risco ambiental e alimentar para a infecção dos animais, e a soronegatividade para Leishmania spp. e T. cruzi pode refletir a ausência desses patógenos em áreas urbanas de Curitiba. Além disso, os cães comunitários podem atuar como sentinelas ambientais quanto à presença de protozoários e seus vetores.

Palavras-chave: Cães comunitários, área urbana, animais sentinela, toxoplasmose, neosporose, RIFI.

\footnotetext{
*Corresponding author: Alexander Welker Biondo. Departamento de Medicina

Veterinária, Universidade Federal do Paraná - UFPR, Rua dos Funcionários, 1540,

CEP 80035-050, Curitiba, PR, Brasil. e-mail: abiondo@ufpr.br
} 
Neighborhood dogs, defined as semi-restricted or free roaming animals with semi-dependence on one or more individuals for food and shelter (WHO \& WSPA, 1990), may act as reservoirs or sentinels for several zoonotic and protozoan infections, particularly in urban areas, thus constituting a potential threat to animal and public health (CABEZÓN et al., 2010; CASTILLO-NEYRA et al., 2015; GÜRTLER \& CARDINAL, 2015; MEIRELES et al., 2004; ROBERTSON et al., 2000; SALB et al., 2008). Although protozoan infection has previously been assessed in different canine populations (AZZAG et al., 2015; COLLANTES-FERNÁNDEZ et al., 2008; LANGONI et al., 2013; TENNEY et al., 2014), the health status of neighborhood dogs remains to be fully established.

In the city of Curitiba, state of Paraná, southern Brazil, neighborhood dogs have spent mostly of their free-roaming lives in densely occupied public areas, such as bus stations and public parks, thus sharing their environment with around 1.1 million daily bus users. Because of the outdoor and free-roaming habits of neighborhood dogs, these dogs may present greater exposure to environmental and vector-borne diseases such as Leishmania spp., Toxoplasma gondii, Trypanosoma cruzi and Neospora caninum (CABEZÓN et al., 2010; SEABRA et al., 2015; TENNEY et al., 2014). For dogs living in stray situation in Brazil, as neighborhood dogs, the seroprevalence for Leishmania spp. have been ranging from $0.0027 \%$ to $32.5 \%$ (FREHSE et al., 2010; SEABRA et al., 2015; TRONCARELLI et al., 2009; VALADAS et al., 2010), for T. gondii from $31.6 \%$ to $68.4 \%$ (MEIRELES et al., 2004; SEABRA et al., 2015; SOUZA et al., 2003; VALADAS et al., 2010), for T. cruzi from $2.0 \%$ to $4.0 \%$ (MORAIS et al., 2013; TRONCARELLI et al., 2009) and for $N$. caninum from $3.2 \%$ to $22.1 \%$ (FRIDLUND-PLUGGE et al., 2008; SEABRA et al., 2015; SOUSA et al., 2012; VALADAS et al., 2010).

Accordingly, the aim of the present study was to evaluate the exposure of neighborhood dogs to four protozoan pathogens in public areas with highly levels of human movement in the city of Curitiba (bus stations and public parks), the eighth biggest city in Brazil.

This study was approved by the Ethics Committee for Animal Experimentation and Animal Welfare of the Federal University of Paraná, state of Paraná, Brazil (protocol number 027/2015).

Bus stations and public parks were included in this study because they are public areas with high and daily human concentration and movement, besides to their good conditions for neighborhood dogs housing. Dog inclusion criteria was applied according to the WHO definition (WHO \& WSPA, 1990) and dogs only included if their correspondent keeper were identified. All 22 bus stations of the city of Curitiba were visited in attempt to identified neighborhood dogs and their respective keeper. In 26 public parks, the neighborhood dogs and their corresponding keeper were registered by population demand by means of city Hall Curitiba phone.

A total of 26 neighborhood dogs were identified in $10 / 22$ bus stations $(45.5 \%)$ and $2 / 26(7.7 \%)$ public parks in the city of Curitiba (252 $5^{\prime} 40^{\prime \prime}$ S; $\left.49^{\circ} 16^{\prime} 23^{\prime \prime} \mathrm{W}\right)$, state of Paraná, southern Brazil, between February and August 2014. These dogs were all of mixed breed, aged $\geq 1$ year, and comprised 9/26 females $(34.1 \%)$ and $17 / 26$ males (65.4\%). An epidemiological questionnaire was applied to corresponding keeper about the dog's environmental conditions and habits such as organic material accumulation, raw meat intake and hunting practices.

Whole blood samples $(5 \mathrm{~mL})$ were collected by means of venipuncture of the jugular vein using sterile vacuum tubes containing serum separator gel (BD Vacutainer, Franklin Lakes, NJ, USA) and were stored at room temperature $\left(25^{\circ} \mathrm{C}\right)$ until visible clot retraction. The samples were centrifuged at $1500 \mathrm{~g}$ for 5 minutes, serum separated and stored at $-20^{\circ} \mathrm{C}$ until serological analysis. The serum samples were tested for specific IgG antibodies against Leishmania spp., Toxoplasma gondii, Trypanosoma cruzi and Neospora caninum by means of the indirect immunofluorescent antibody test (IFAT), as previously described (CAMARGO, 1974). Both, positive and negative, control sera were provided by the Núcleo de Pesquisa em Zoonoses (NUPEZO), Universidade Estadual Paulista (UNESP), Botucatu - SP for all the four diseases. Samples were considered reactive when antibody titers $\geq 40$ for Leishmania spp., $\geq 16$ for $T$. gondii, $\geq 20$ for $T$. cruzi and $\geq 25$ for $N$. caninum were found. The titers were determined to the largest dilution at which fluorescence was viewed around the protozoa (endpoint titers). Fisher's exact test was used to determine differences relating to whether individual factors were associated with seroreactivity through IFAT. Moreover, the Spearman correlation coefficient was calculated to verify the correlation between daily human movement and seroreactivity. Results were considered to be statistically significant when $\mathrm{p}<0.05$. Data were stored and analyzed using commercially available software (Epi Info, version 7.1.5.2, CDC, Atlanta, USA).

In total, $3 / 26$ neighborhood dogs (11.5\%; 95\% CI: 2.35-29.16\%) were seroreactive to $N$. caninum, with antibody titers ranging from 25 to $200 ; 8 / 26$ (30.7\%; 95\% CI: 14.33-51.79\%) were seroreactive to $T$. gondii, with antibodies titers ranging from 16 to 64 ; and only $2 / 26(7.7 \%)$ were seroreactive to both (Figure 1). All the dogs were seronegative to Leishmania spp. and T. cruzi. No significant associations were found between gender, diet, raw meat intake or hunting practices and seroreactivity to $N$. caninum and/or $T$. gondii. The seroprevalence results for $N$. caninum and $T$. gondii among the neighborhood dogs and the respective variables are presented in Table 1 and Table 2. Likewise, no correlation was found between daily high human movement and seroreactivity to $N$. caninum (Spearman correlation coefficient $=-0.174 ; p=0.631$ ) and $/$ or T. gondii (Spearman correlation coefficient $=0.302 ; p=0.397$ ) (Figure 1). However, the neighborhood dogs appear at bus stations where there are a higher population density, and also that the dogs seronegative for all surveyed pathogens represent the most these locations (Figure 2).

Surprisingly, to the best of our knowledge, this study was the first serosurvey on this dog population worldwide. Despite the outdoor and free-roaming habits of neighborhood dogs, which may increase their exposure to protozoan infections (AZEVEDO et al., 2005; COLLANTES-FERNÁNDEZ et al., 2008; MOURA et al., 2009; NAZIR et al., 2014), they presented in this study a low seroprevalence for $T$. gondii and $N$. caninum compared with literature results (MEIRELES et al., 2004; SEABRA et al., 2015; VALADAS et al., 2010), which may indicate that there was a situation of low environmental oocyst contamination (MEIRELES et al., 2004). 


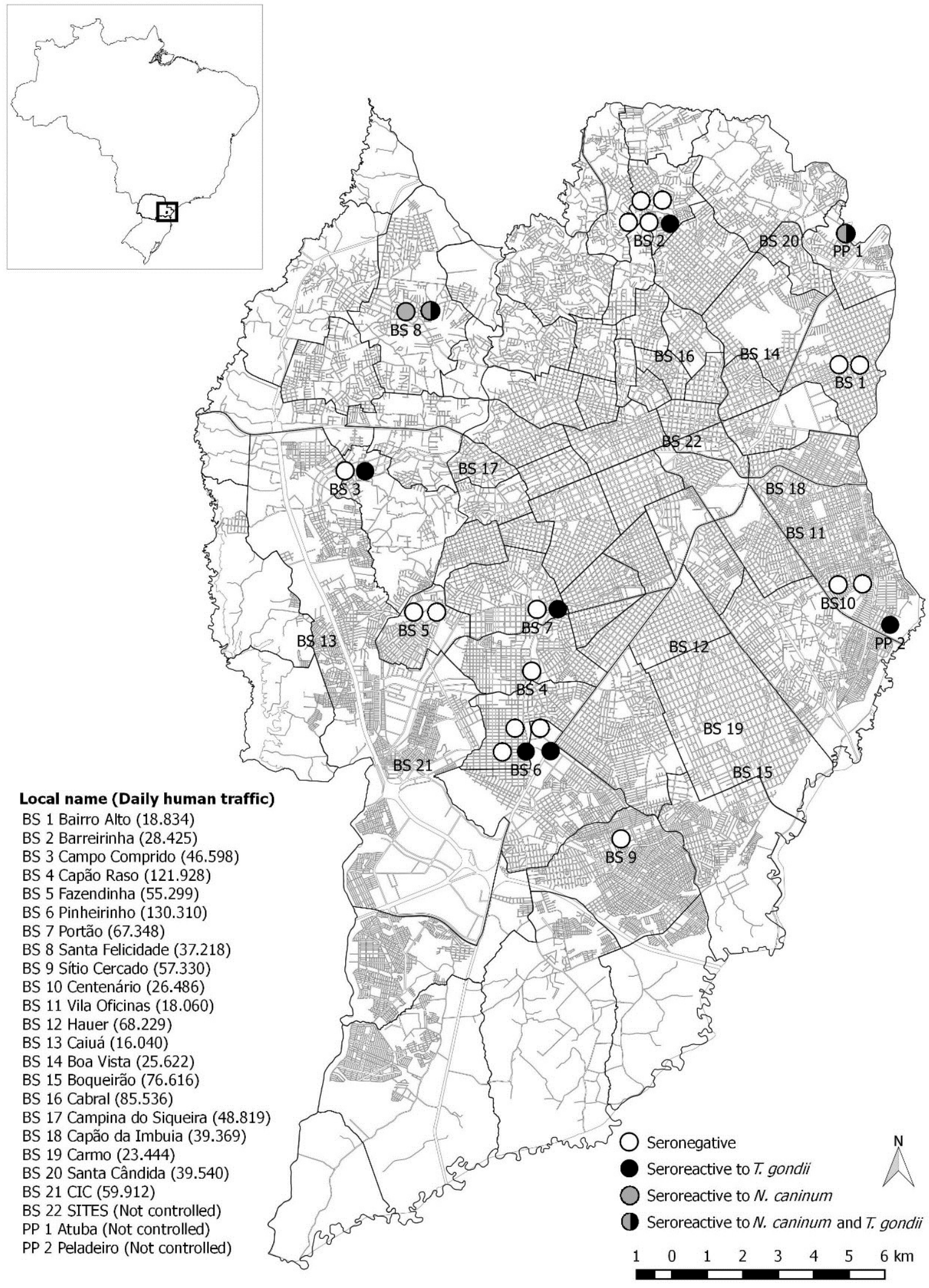

SRC SAD69/UTM zone 225

Source: IPPUC 2016

Figure 1. Map of Brazil showing the location of the state of Paraná and city of Curitiba. Enlarged map shows the spatial distribution of neighborhood dogs according to blood test results, in relation to Leishmania spp., Toxoplasma gondii, Trypanosoma cruzi and Neospora caninum, and daily human movements in bus stations (BS) and public parks (PP) included in the study, city of Curitiba, state of Paraná, southern Brazil, 2016. 


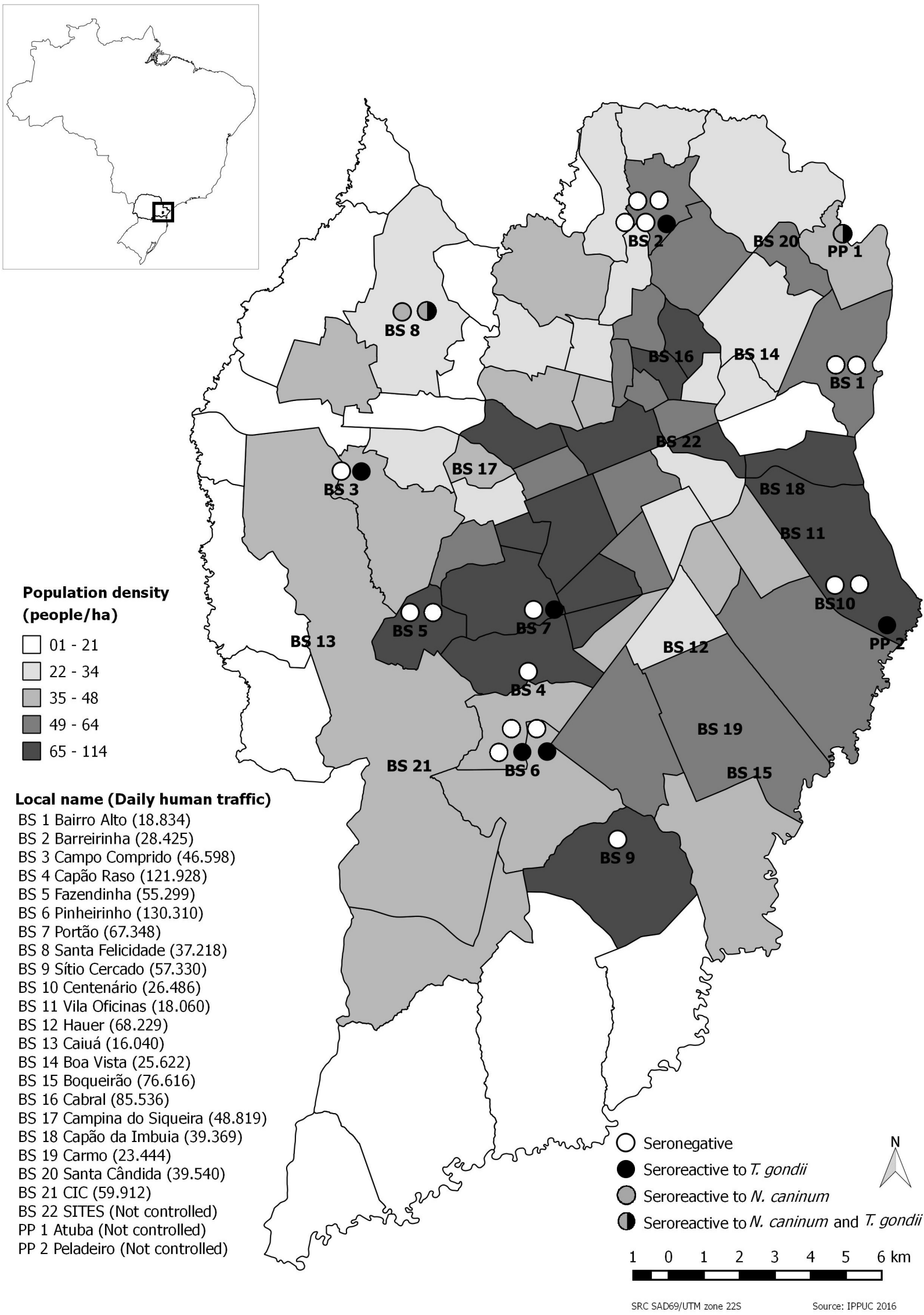

Figure 2. Map of Brazil showing the location of the state of Paraná and city of Curitiba. Enlarged map shows the spatial distribution of neighborhood dogs according to blood test results in relation to population density of city of Curitiba, state of Paraná, southern Brazil, 2016. 
Table 1. Seroprevalence for Neospora caninum and Toxoplasma gondii among neighborhood dogs according to IFAT, in relation to each variable studied, city of Curitiba, state of Paraná, southern Brazil, 2016.

\begin{tabular}{|c|c|c|c|c|c|c|c|c|}
\hline \multirow{2}{*}{ Variable } & \multicolumn{4}{|c|}{ Neospora caninum } & \multicolumn{4}{|c|}{ Toxoplasma gondii } \\
\hline & $+/ \mathrm{N}(\%)$ & OR & $95 \% \mathrm{CI}$ & $p$-value & $+/ \mathrm{N}(\%)$ & OR & $95 \% \mathrm{CI}$ & $p$-value \\
\hline \multicolumn{9}{|l|}{ Gender } \\
\hline Male & $1 / 17(5.9 \%)$ & 0.50 & $0.01-44.10$ & 1.0000 & $3 / 17(17.6 \%)$ & 0.17 & $0.02-1.42$ & 0.0781 \\
\hline Female & $2 / 9(22.2 \%)$ & Ref. & & & $5 / 9(55.6 \%)$ & Ref. & & \\
\hline \multicolumn{9}{|c|}{ Hunting practice } \\
\hline Yes & $1 / 8(12.5 \%)$ & 1.14 & $0.02-25.42$ & 1.0000 & $2 / 8(25.0 \%)$ & 0.66 & $0.05-5.56$ & 1.0000 \\
\hline No & $2 / 18(11.1 \%)$ & Ref. & & & $6 / 18(33.3 \%)$ & Ref. & & \\
\hline \multicolumn{9}{|c|}{ Raw meat intake } \\
\hline Yes & $1 / 5(20.0 \%)$ & 2.4 & $0.03-55.07$ & 0.9769 & $1 / 5(20.0 \%)$ & 0.50 & $0.09-6.63$ & 1.0000 \\
\hline No & $2 / 21(9.5 \%)$ & Ref. & & & $7 / 21(33.3 \%)$ & Ref. & & \\
\hline
\end{tabular}

+: number of positive animals; $\mathrm{N}$ : number of samples per variable; OR: odds ratio; 95\% CI: 95\% confidence interval; Ref.: variable used as a reference value; -: undetermined.

Table 2. Seroprevalence for Toxoplasma gondii and Neospora caninum among neighborhood dogs according to IFAT, in relation to each gender and housing location of neighborhood dogs, city of Curitiba, state of Paraná, southern Brazil, 2016.

\begin{tabular}{|c|c|c|c|c|c|}
\hline \multirow{2}{*}{ HOUSING LOCATION } & \multirow{2}{*}{$\mathbf{N}$} & \multicolumn{2}{|c|}{ SEROREACTIVES FOR $T$. gondii } & \multicolumn{2}{|c|}{ SEROREACTIVES FOR $N$. caninum } \\
\hline & & $\mathbf{M} / \mathbf{n}(\%)$ & F/n $(\%)$ & $\mathbf{M} / \mathbf{n}(\%)$ & F/n (\%) \\
\hline BS Bairro Alto & 2 & $0 / 2(0)$ & $0 / 0(0)$ & $0 / 2(0)$ & $0 / 0(0)$ \\
\hline BS Barreirinha & 5 & $0 / 3(0)$ & $1 / 2(50)$ & $0 / 3(0)$ & $0 / 2(0)$ \\
\hline BS Campo Comprido & 2 & $0 / 1(0)$ & $1 / 1(100)$ & $0 / 1(0)$ & $0 / 1(0)$ \\
\hline BS Capão Raso & 1 & $0 / 0(0)$ & $0 / 1(0)$ & $0 / 0(0)$ & $0 / 1(0)$ \\
\hline BS Centenário & 2 & $0 / 1(0)$ & $0 / 1(0)$ & $0 / 1(0)$ & $0 / 1(0)$ \\
\hline BS Pinheirinho & 5 & $2 / 4(50)$ & $0 / 1(0)$ & $0 / 4(0)$ & $0 / 1(0)$ \\
\hline BS Portão & 2 & $0 / 1(0)$ & $1 / 1(100)$ & $0 / 1(0)$ & $0 / 1(0)$ \\
\hline BS Santa Felicidade & 2 & $0 / 1(0)$ & $1 / 1(100)$ & $1 / 1(100)$ & $1 / 1(100)$ \\
\hline BS Sítio Cercado & 1 & $0 / 1(0)$ & $0 / 0(0)$ & $0 / 1(0)$ & $0 / 0(0)$ \\
\hline BS Fazendinha & 2 & $0 / 2(0)$ & $0 / 0(0)$ & $0 / 2(0)$ & $0 / 0(0)$ \\
\hline PP Atuba & 1 & $0 / 0(0)$ & $1 / 1(100)$ & $0 / 0(0)$ & $1 / 1(100)$ \\
\hline PP Peladeiro & 1 & $1 / 1(100)$ & $0 / 0(0)$ & $0 / 1(0)$ & $0 / 0(0)$ \\
\hline TOTAL & 26 & $3 / 17(17.6)$ & $5 / 9(55.6)$ & $1 / 17(5.9)$ & $2 / 9(22.2)$ \\
\hline
\end{tabular}

BS: bus station; PP: public park; N: number of samples tested; M: male; F: female; n: number of samples per gender.

Since dogs play a secondary role in the toxoplasmosis cycle, neighborhood dogs may be considered to be true environmental sentinels for T. gondii, particularly when sharing a contaminated urban environment and contaminated food and water (MEIRELES et al., 2004). In contrast, as the definitive hosts of $N$. caninum, dogs may play an important role in spreading this disease (NAZIR et al., 2014).

As expected, all the neighborhood dogs tested negative for Leishmania spp. and T. cruzi in the present study. In fact, the city of Curitiba has been considered to be a non-endemic area for both of these diseases and, thus, these results may reflect the historical absence of vectors and pathogens (BRASIL, 2014a, b). However, canine visceral leishmaniasis was previously detected in $1 / 364$ stray dogs $(0.0027 \%)$ from a city situated close to Curitiba (FREHSE et al., 2010), and triatomine (T. cruzi vector) infestation was detected in 7/9 cities (77.8\%) in the northern part of the state of Paraná (FALAVIGNA-GUILHERME et al., 2004). Moreover, the first autochthonous case of human visceral leishmaniasis in the state of Paraná was registered in 2015 in city of Foz do Iguaçu, and the first death due to this disease was reported in January 2016 (AEN, 2015). Since infection of dogs by Leishmania spp. may precede human cases (OLIVEIRA et al., 2001), periodic serosurveys among neighborhood dogs may be used as a means of active surveillance in non-endemic areas such as the city of Curitiba.

In conclusion, despite daily exposure of these neighborhood dogs to risk of infection, in public areas of Curitiba, the protozoan seroprevalence for $N$. caninum and T. gondii was within the general population range and may indicate that there was a situation of low environmental and food risk with regard to animal infection. Furthermore, the absence of antibodies anti-Leishmania spp. and T. cruzi may reflect de absence of theses pathogens in urban areas of Curitiba. Moreover, neighborhood dogs may be used as environmental sentinels for the presence of these protozoan pathogens and their transmission vectors in non-endemic areas. 


\section{Acknowledgements}

We thank the staff of the Zoonosis Research Center, UNESP, city of Botucatu and Curitiba Animal Service for their in-field assistance. We thank the Araucaria Support Foundation for Scientific and Technological Development of the State of Paraná for the full financial support for this research and the Coordination Office for Improvement of Higher-Education Personnel for the master's fellowship.

\section{References}

Agência Estadual de Notícias do Paraná - AEN. Paraná registra primeiro caso de leishmaniose visceral em humanos [online]. Curitiba, 2015 [cited 2015 Jul 16]. Available from: http://www.aen.pr.gov.br/modules/noticias/ article.php?storyid $=84980$

Azevedo SS, Batista CS, Vasconcellos SA, Aguiar DM, Ragozo AM, Rodrigues AA, et al. Seroepidemiology of Toxoplasma gondii and Neospora caninum in dogs from the state of Paraíba, Northeast region of Brazil. Res Vet Sci 2005; 79(1): 51-56. PMid:15894024. http://dx.doi.org/10.1016/j. rvsc.2004.10.001.

Azzag N, Petit E, Gandoin C, Bouillin C, Ghalmi F, Haddad N, et al. Prevalence of select vector-borne pathogens in stray and client-owned dogs from Algiers. Comp Immunol Microbiol Infect Dis 2015; 38: 1-7. PMid:25638478. http://dx.doi.org/10.1016/j.cimid.2015.01.001.

Brasil. Ministério da Saúde. Secretaria de Vigilância em Saúde - SVS. Sistema de Informação de Agravos de Notificação - SINAN. Doença de chagas aguda - casos confirmados notificados no sistema de informação de agravos de notificação - Paraná [online]. Brasília, 2014a [cited 2016 May 29]. Available from: http://tabnet.datasus.gov.br/cgi/deftohtm. exe?sinannet/cnv/chagasPR.def

Brasil. Ministério da Saúde. Secretaria de Vigilância em Saúde - SVS. Sistema de Informação de Agravos de Notificaçáo - SINAN. Leishmaniose visceral - casos confirmados notificados no sistema de informação de agravos de notificação - Paraná [online]. Brasília, 2014b [cited 2016 May 29]. Available from: http://tabnet.datasus.gov.br/cgi/tabcgi.exe?sinannet/ cnv/leishvPR.def

Cabezón O, Millán J, Gomis M, Dubey JP, Ferroglio E, Almería S. Kennel dogs as sentinels of Leishmania infantum, Toxoplasma gondii, and Neospora caninum in Majorca Island, Spain. Parasitol Res 2010; 107(6): 15051508. PMid:20689966. http://dx.doi.org/10.1007/s00436-010-2015-7.

Camargo ME. Introdução às técnicas de imunofluorescência. Rev Bras Patol Clin 1974; 10(30): 143-169.

Castillo-Neyra R, Chu LC, Quispe-Machaca V, Ancca-Juarez J, Chavez FSM, Mazuelos M, et al. The potential of canine sentinels for reemerging Trypanosoma cruzi transmission. Prev Vet Med 2015; 120(3): 349-356. PMid:25962956. http://dx.doi.org/10.1016/j.prevetmed.2015.04.014.

Collantes-Fernández E, Gómez-Bautista M, Miró G, Alvarez-García G, Pereira-Bueno J, Frisuelos C, et al. Seroprevalence and risk factors associated with Neospora caninum infection in different dog populations in Spain. Vet Parasitol 2008; 152(1-2): 148-151. PMid:18241992. http:// dx.doi.org/10.1016/j.vetpar.2007.12.005.

Falavigna-Guilherme AL, Santana R, Pavanelli GC, Lorosa ES, Araújo SM. Triatomine infestation and vector-borne transmission of Chagas disease in northwest and central Paraná, Brazil. Cad Saude Publica 2004;
20(5): 1191-1200. PMid:15486661. http://dx.doi.org/10.1590/S0102311X2004000500012.

Frehse MS, Greca Júnior H, Ullmann LS, Camossi LG, Machado JG, Langoni $\mathrm{H}$, et al. Surveillance of canine visceral leishmaniasis in a diseasefree area. Rev Bras Parasitol Vet 2010; 19(1): 62-64. PMid:20385062. http://dx.doi.org/10.4322/rbpv.01901011.

Fridlund-Plugge N, Montiani-Ferreira F, Richartz RR, Dal Pizzol J, Machado PC Jr, Patrício LF, et al. Frequency of antibodies against Neospora caninum in stray and domiciled dogs from urban, periurban and rural areas from Paraná State, Southern Brazil. Rev Bras Parasitol Vet 2008; 17(4): 222-226. PMid:19265582.

Gürtler RE, Cardinal MV. Reservoir host competence and the role of domestic and commensal hosts in the transmission of Trypanosoma cruzi. Acta Trop 2015; 151:32-50. PMid:26051910. http://dx.doi.org/10.1016/j. actatropica.2015.05.029.

Langoni H, Fornazari F, Silva RCD, Monti ET, Villa FB. Prevalence of antibodies against Toxoplasma gondii and Neospora caninum in dogs. Braz J Microbiol 2013; 44(4): 1327-1330. PMid:24688530. http://dx.doi. org/10.1590/S1517-83822013000400043.

Meireles LR, Galisteo AJ Jr, Pompeu E, Andrade HF Jr. Toxoplasma gondii spreading in an urban area evaluated by seroprevalence in free-living cats and dogs. Trop Med Int Health 2004; 9(8): 876-881. PMid:15303992. http://dx.doi.org/10.1111/j.1365-3156.2004.01280.x.

Morais AN, Sousa MG, Meireles LR, Kesper N Jr, Umezawa ES. Canine visceral leishmaniasis and Chagas disease among dogs in Araguaína, Tocantins. Rev Bras Parasitol Vet 2013; 22(2): 225-229. PMid:23802237. http://dx.doi.org/10.1590/S1984-29612013005000024.

Moura AD, Souza AD, Sartor AA, Bellato V, Teixeira EB, Pisetta GM, et al. Ocorrência de anticorpos e fatores de risco para infecção por Toxoplasma gondii em cães, nas cidades de Lages e Balneário Camboriú, Santa Catarina, Brasil. Rev Bras Parasitol Vet 2009; 18(3): 52-56. PMid:19772776. http:// dx.doi.org/10.4322/rbpv.01803009.

Nazir MM, Maqbool A, Akhtar M, Ayaz M, Ahmad AN, Ashraf K, et al. Neospora caninum prevalence in dogs raised under different living conditions. Vet Parasitol 2014; 204(3-4): 364-368. PMid:24957000. http://dx.doi.org/10.1016/j.vetpar.2014.05.041.

Oliveira CDL, Assunção RM, Reis IA, Proietti FA. Spatial distribution of human and canine visceral leishmaniasis in Belo Horizonte, Minas Gerais State, Brasil, 1994-1997. Cad Saude Publica 2001; 17(5): 1231-1239. PMid:11679897. http://dx.doi.org/10.1590/S0102-311X2001000500023.

Robertson ID, Irwin PJ, Lymbery AJ, Thompson RCA. The role of companion animals in the emergence of parasitic zoonoses. Int J Parasitol 2000; 30(12-13): 1369-1377. PMid:11113262. http://dx.doi.org/10.1016/ S0020-7519(00)00134-X.

Salb AL, Barkema HW, Elkin BT, Thompson RCA, Whiteside DP, Black SR, et al. Dogs as sources and sentinels of parasites in humans and wildlife, northern Canada. Emerg Infect Dis 2008; 14(1): 60-63. PMid:18258078. http://dx.doi.org/10.3201/eid1401.071113.

Seabra NM, Pereira VF, Kuwassaki MV, Benassi JC, Oliveira TMFS. Toxoplasma gondii, Neospora caninum and Leishmania spp. serology and Leishmania spp. PCR in dogs from Pirassununga, SP. Rev Bras Parasitol Vet 2015; 24(4): 454-458. PMid:26689180. http://dx.doi.org/10.1590/ S1984-29612015046.

Sousa ME, Porto WJN, Albuquerque PPF, Souza OL No, Pinheiro JW Jr, Mota RA. Seroprevalence of antibodies to Neospora caninum in dogs in 
the state of Alagoas, Brazil. Rev Bras Parasitol Vet 2012; 21(3): 287-290. PMid:23070441. http://dx.doi.org/10.1590/S1984-29612012000300019.

Souza SLP, Gennari SM, Yai LEO, D'Auria SRN, Cardoso SMS, Guimarães JS Jr, et al. Occurrence of Toxoplasma gondii antibodies in sera from dogs of the urban and rural areas from Brazil. Rev Bras Parasitol Vet 2003; 12(1): 1-3.

Tenney TD, Curtis-Robles R, Snowden KF, Hamer SA. Shelter dogs as sentinels for Trypanosoma cruzi transmission across Texas, USA. Emerg Infect Dis 2014; 20(8): 1323-1326. PMid:25062281. http://dx.doi. org/10.3201/eid2008.131843.

Troncarelli MZ, Camargo JB, Machado JG, Lucheis SB, Langoni H. Leishmania spp. and/or Trypanosoma cruzi diagnosis in dogs from endemic and nonendemic areas for canine visceral leishmaniasis. Vet Parasitol 2009; 164(2-4): 118-123. PMid:19625128. http://dx.doi.org/10.1016/j. vetpar.2009.06.027.

Valadas S, Minervino AH, Lima VF, Soares RM, Ortolani EL, Gennari SM. Occurrence of antibodies anti-Neospora caninum, anti-Toxoplasma gondii, and anti-Leishmania chagasi in serum of dogs from Pará State, Amazon, Brazil. Parasitol Res 2010; 107(2): 453-457. PMid:20445991. http://dx.doi.org/10.1007/s00436-010-1890-2.

World Health Organization - WHO. World Society for the Protection of Animals - WSPA. Guidelines for dog population management. Geneva: WHO; 1990 